\title{
PHENOTYPIC PLASTICITY IN COLONIZING POPULATIONS OF Drosophila subobscura
}

\author{
Glòria Pegueroles, Francesc Mestres, Mercè Argemí and Lluís Serra
}

\begin{abstract}
The phenotypic plasticity of some quantitative traits of two colonizing populations of Drosophila subobscura (Davis and Eureka, California) was studied. Temperature effects and the effect of rearing in the laboratory were studied. Laboratory rearing during four generations at $18^{\circ} \mathrm{C}$ significantly increased the wing and tibial length. This increase was similar to that obtained when the flies were reared at $13^{\circ} \mathrm{C}$ during two generations. The low temperature environment can be considered more stressful for females than for males, as shown by the increase of phenotypic variance. The two populations analyzed had great phenotypic plasticity in spite of the genetic bottleneck during the colonization event. Our study shows that keeping flies for a relatively short time in the laboratory significantly changes some quantitative traits, emphasizing the need to analyze flies immediately after collecting them in order to obtain reliable estimates for the analysis of these traits in natural populations.
\end{abstract}

\section{INTRODUCTION}

In general, flies from cooler regions tend to be larger than flies from warmer regions. Both Bergmann's and Allen's rules express the relationship between body surface and environmental temperature, but these rules may or may not concern heat conservation in poikilotherms (Ray, 1960). Size seems to be genetically controlled. Populations maintained in the laboratory at different temperatures diverge genetically with respect to body size (Anderson, 1966, 1973; Powell, 1974; Cavicci et al., 1989). Furthermore, Drosophila flies from humid tropical and temperate zones grown at different temperatures show a similar trend in body size and weight phenotypic differentiation (Ray, 1960). Powell (1974) suggested that some populations show genetic variation for body size for reasons other than temperature adaptations and it is only in the artificial, laboratory environment that temperature is the selective force on this variance. On the other hand, phenotypic variance has been shown to increase in stressful environments (Burla and Taylor, 1982; Barker and Krebs, 1995), suggesting that this phenomenon could contribute to the increase observed in genetic variation in marginal environments, with more rapid evolution during periods of special stress.

Phenotypic plasticity is exhibited as environmentally mediated change in the phenotype (Via et al., 1995). Although the study of phenotypic responses has a long history recently there has been a new interest in this phenomenon at both theoretical and experimental levels (review in Via, 1994). Laboratory conditions constitute a completely new environment for the flies, in which genetic variation for body size could be expressed in a different way from the wild. Drosophila subobscura is a Palearctic

Departament de Genètica, Facultat de Biologia, Universitat de Barcelona, Av. Diagonal, 645, 08071 Barcelona, Spain. Send correspondence to L.S. Fax: +34-3-411-0969. E-mail lluis@ porthos.bio.ub.es species distributed all over Europe (Krimbas, 1993). This species was detected for the first time in Puerto Montt (Chile) in February 1978 (Brncic et al., 1981) and subsequently it has spread very quickly all over the country. It was also detected in North America in summer 1982 (Beckenbach and Prevosti, 1986) and has become established all over the Western Pacific coast, from British Columbia to Ojai (California) (Prevosti et al., 1989). We examined two colonizing populations to ascertain whether the genetic bottleneck that took place during the founder event (Prevosti et al., 1983; Ayala et al., 1989; Mestres et al.; 1990, Balanyà et al., 1994) had any influence on the phenotypic plasticity of this species.

\section{MATERIAL AND METHODS}

Two American populations of D. subobscura, Davis and Eureka (California) were analyzed. The population of Davis ( $\left.38^{\circ} 32^{\prime} \mathrm{N}, 121^{\circ} 46^{\prime} \mathrm{W}\right)$ is located in the Californian Central Valley (altitude $18 \mathrm{~m}$ ) and has extreme weather conditions (the range of temperatures is between $-6.1^{\circ} \mathrm{C}$ and $43.9^{\circ} \mathrm{C}$, annual average $16.2^{\circ} \mathrm{C}$, annual rain $345 \mathrm{~mm})$. Eureka $\left(40^{\circ} 48^{\prime} \mathrm{N}, 124^{\circ} 10^{\prime} \mathrm{W}\right)$ is a coastal locality (altitude $18 \mathrm{~m}$ ) in Northern California (the range of temperatures is between $-2.8^{\circ} \mathrm{C}$ and $27.8^{\circ} \mathrm{C}$, annual average $12.2^{\circ} \mathrm{C}$; annual rain $803 \mathrm{~mm}$ ). Six quantitative traits were studied in males: wing length was measured along longitudinal vein IV, divided into two segments, $\mathrm{L}_{1}$ (from the base of the fourth longitudinal vein to the posterior cross vein) and $\mathrm{L}_{2}$ (from the posterior cross vein to the extreme of the media, according to Robertson and Reeve (1952) and Prevosti (1955)); wing width (W) from the extreme of the V vein to the costal border, running perpendicular to the third vein (Figure 1); tibial length (TL), and two meristic traits: number of teeth of the proximal (PC) and distal (DC) sex combs (on the right leg). In females only the continuous variables $\mathrm{L}_{1}, \mathrm{~L}_{2}, \mathrm{~W}$ and $\mathrm{TL}$ were analyzed.

The experimental procedure for each population 


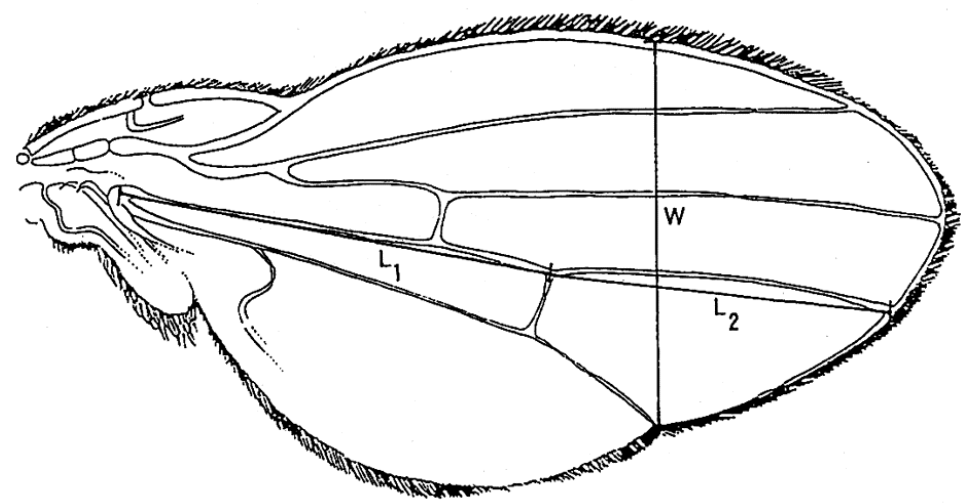

Figure 1 - Continuous variables measured in the wing of D. subobscura $\left(\mathrm{L}_{1}, \mathrm{~L}_{2}\right.$, and W). See text for details.

was as follows: 10 wild females were placed in individual rearing vials at $18^{\circ} \mathrm{C}$. All the $\mathrm{F}_{1}$ offspring from each vial were put into plastic chambers measuring $13 \times 9 \times 6 \mathrm{~cm}$ (one plastic chamber for each vial) to obtain eggs. One day later, 100 eggs were collected from each of the 10 chambers and placed in individual vials (100 eggs per vial) in order to prevent larval competition and kept at $18^{\circ} \mathrm{C}$. The same procedure was repeated with another independent sample of 10 wild females but the vials were keat at $13^{\circ} \mathrm{C}$. For measuring the quantitative traits $10 \mathrm{~F}_{2}$ males and $10 \mathrm{~F}_{2}$ females were selected at random from each vial. Thus, 100 $\mathrm{F}_{2}$ males and $100 \mathrm{~F}_{2}$ females were analyzed for each temperature $\left(18^{\circ}\right.$ and $\left.13^{\circ} \mathrm{C}\right)$. All these adult flies were preserved in glycerine-alcohol (1:2) until the measurement of the quantitative traits. The remaining $\mathrm{F}_{2}$ offspring kept at $18^{\circ} \mathrm{C}$ were maintained for two generations at the same temperature (100 eggs were chosen at random from each chamber in each generation to prevent larval competition), and the same procedure for the measurement of quantitative traits was carried out in the $\mathrm{F}_{4}$ generation. The measurements were made under a compound microscope at 50X magnification with an ocular micrometer. Wing length and width and tibial length were recorded to the nearest unit of the micrometer scale, which corresponded to $0.029 \mathrm{~mm}$.

The data were statistically analyzed by ANOVAS for each variable and by three one-way multivariate analyses of variance (MANOVA), considering as factors the temperature $\left(13^{\circ}\right.$ and $\left.18^{\circ} \mathrm{C}\right)$, the population (Davis and Eureka) and the number of generations in the laboratory at $18^{\circ} \mathrm{C}\left(\mathrm{F}_{2}\right.$ and $\mathrm{F}_{4}$ ), respectively. In all cases sexes were analyzed separately due to the significant sexual differences in the variables analyzed. A canonical analysis to study the differences among the six characterized groups (Eureka $18^{\circ} \mathrm{CF}_{2}$, Davis $18^{\circ} \mathrm{C} \mathrm{F}_{2}$, Eureka $13^{\circ} \mathrm{C} \mathrm{F}_{2}$, Davis $13^{\circ} \mathrm{C} \mathrm{F}_{2}$, Eureka $18^{\circ} \mathrm{C} \mathrm{F}_{4}$ and Davis $18^{\circ} \mathrm{C} \mathrm{F}_{4}$ ) was also performed.

\section{RESULTS}

The mean values for the continuous variables $\mathrm{L}_{1}$, $\mathrm{L}_{2}, \mathrm{~W}$ and TL (Tables I and II) were very similar for the
Table I - Mean value (M) and standard error (SE) of the continuous variables L1, L2, W and TL, for the Drosophila subobscura females of each group - Eureka $18^{\circ} \mathrm{F}_{2}$, Davis $18^{\circ} \mathrm{F}_{2}$, Eureka $13^{\circ} \mathrm{F}_{2}$, Davis $13^{\circ} \mathrm{F}_{2}$, Eureka $18^{\circ} \mathrm{F}_{4}$ and Davis $18^{\circ} \mathrm{F}_{4}$ (100 individuals measured in each group).

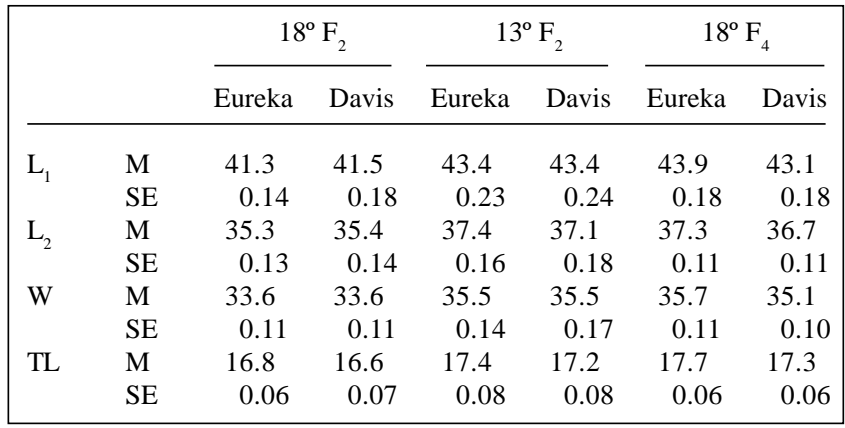

L1 and L2: Segments from the base of the fourth longitudinal vein to the posterior cross vein and from the posterior cross vein to the extreme of the media, respectively; $\mathrm{W}=$ wing width from the extreme of the $\mathrm{V}$ vein to the costal border, running perpendicular to the third vein; $\mathrm{TL}=$ tibial length .

Table II - Mean value (M) and standard error (SE) of the continuous variables $\mathrm{L} 1, \mathrm{~L} 2, \mathrm{~W}$ and $\mathrm{TL}$ and the meristic variables DC and PC, for the Drosophila subobscura males of each characterized group - Eureka $18^{\circ}$ $\mathrm{F}_{2}$, Davis $18^{\circ} \mathrm{F}_{2}$, Eureka $13^{\circ} \mathrm{F}_{2}$, Davis $13^{\circ} \mathrm{F}_{2}$, Eureka $18^{\circ} \mathrm{F}_{4}$ and Davis $18^{\circ}$ $\mathrm{F}_{4}$ (100 individuals measured in each group).

\begin{tabular}{|c|c|c|c|c|c|c|c|}
\hline & & \multicolumn{2}{|c|}{$18^{\circ} \mathrm{F}_{2}$} & \multicolumn{2}{|c|}{$13^{\circ} \mathrm{F}_{2}$} & \multicolumn{2}{|c|}{$18^{\circ} \mathrm{F}_{4}$} \\
\hline & & Eureka & Davis & Eureka & Davis & Eureka & Davis \\
\hline \multirow{2}{*}{$\mathrm{L}_{1}$} & M & 37.1 & 37.1 & 39.2 & 38.9 & 38.9 & 38.5 \\
\hline & SE & 0.13 & 0.17 & 0.16 & 0.21 & 0.20 & 0.16 \\
\hline \multirow{2}{*}{$\mathrm{L}_{2}$} & M & 32.7 & 32.8 & 34.4 & 33.8 & 33.8 & 33.8 \\
\hline & SE & 0.10 & 0.12 & 0.12 & 0.14 & 0.12 & 0.11 \\
\hline \multirow[t]{2}{*}{ W } & M & 30.8 & 30.9 & 32.4 & 32.1 & 32.3 & 32.1 \\
\hline & SE & 0.10 & 0.11 & 0.11 & 0.16 & 0.12 & 0.09 \\
\hline \multirow[t]{2}{*}{$\mathrm{TL}$} & M & 17.3 & 17.4 & 18.0 & 17.7 & 17.9 & 18.0 \\
\hline & SE & 0.08 & 0.07 & 0.08 & 0.08 & 0.08 & 0.07 \\
\hline \multirow[t]{2}{*}{ DC } & M & 9.5 & 9.2 & 9.8 & 9.8 & 9.8 & 9.8 \\
\hline & SE & 0.12 & 0.11 & 0.12 & 0.11 & 0.12 & 0.11 \\
\hline \multirow[t]{2}{*}{ PC } & M & 10.4 & 10.6 & 11.4 & 11.4 & 10.9 & 11.3 \\
\hline & SE & 0.11 & 0.13 & 0.12 & 0.13 & 0.11 & 0.11 \\
\hline
\end{tabular}

$\mathrm{DC}$ and $\mathrm{PC}=$ Distal and proximal sex combs. For other abbreviations see legend to Table I. 
Table III - Results of F-test for the comparisons of variances between $18^{\circ} \mathrm{C}\left(\mathrm{F}_{2}\right.$ and $\left.\mathrm{F}_{4}\right)$ and $13^{\circ} \mathrm{C}\left(\mathrm{F}_{2}\right)$ for Drosophila subobscura females in both populations (Davis and Eureka).

\begin{tabular}{|c|c|c|c|c|c|c|c|c|c|}
\hline & & \multicolumn{2}{|c|}{$\mathrm{L}_{1}$} & \multicolumn{2}{|c|}{$\mathrm{L}_{2}$} & \multicolumn{2}{|c|}{ W } & \multicolumn{2}{|c|}{$\mathrm{TL}$} \\
\hline & & F & $\mathrm{P}$ & $\mathrm{F}$ & $\mathrm{P}$ & $\mathrm{F}$ & $\mathrm{P}$ & $\mathrm{F}$ & $\mathrm{P}$ \\
\hline \multirow[t]{2}{*}{ Eureka } & $18^{\circ} \mathrm{F}_{2}-13^{\circ} \mathrm{F}_{2}$ & 2.746 & 0.0001 & 1.433 & 0.0376 & 1.871 & 0.0010 & 1.979 & 0.0004 \\
\hline & $18^{\circ} \mathrm{F}_{4}-13^{\circ} \mathrm{F}_{2}^{2}$ & 1.661 & 0.0061 & 1.955 & 0.0005 & 1.803 & 0.0018 & 1.631 & 0.0079 \\
\hline \multirow[t]{2}{*}{ Davis } & $18^{\circ} \mathrm{F}_{2}-13^{\circ} \mathrm{F}_{2}$ & 1.848 & 0.0012 & 1.694 & 0.0047 & 2.495 & 0.0001 & 1.490 & 0.0243 \\
\hline & $18^{\circ} \mathrm{F}_{4}^{2}-13^{\circ} \mathrm{F}_{2}^{2}$ & 1.912 & 0.0007 & 2.589 & 0.0001 & 2.974 & 0.0001 & 2.120 & 0.0001 \\
\hline
\end{tabular}

For abbreviations see Table I.

$13^{\circ} \mathrm{C} \mathrm{F}_{2}$ and $18^{\circ} \mathrm{C} \mathrm{F}_{4}$ groups, in both sexes. Furthermore, the $13^{\circ} \mathrm{C}$ environment could be classified as more stressful for the females, as shown by the higher values of the standard deviation in this sex. The differences between the standard deviation at $13^{\circ}$ and $18^{\circ} \mathrm{C}$ were significant at the 0.05 level for the females in all cases (Table III).

A comparison was made between $\mathrm{F}_{2}$ and $\mathrm{F}_{4}$ females from Davis reared at $18^{\circ} \mathrm{C}$ to determine the effect of rearing in the laboratory (Table IV). For the multivariate case, there was homogeneity of the variance-covariance matrices $(P=0.174)$ and the difference between the mean vectors was significant $(\mathrm{F}=34.78$ with 4 and 195 d.f.). The results were similar for the males from Davis and for both sexes in Eureka.

A comparison between $\mathrm{F}_{2}$ males from Eureka at $13^{\circ}$ and $18^{\circ} \mathrm{C}$ was made to determine the effect of temperature (Table V). Although in this case the Box-M test of homogeneity of the variance-covariance matrices is significant $(\mathrm{P}=0.011)$, the use of the MANOVA procedure is still justified because most of the signs of the correlation coefficients coincide. A decrease of $5^{\circ} \mathrm{C}$ provoked a clear increase in the variances (Table III), which could reflect a loss of homeostasis. Furthermore, the mean vectors were also significantly different. This result is in agreement with those obtained by other authors (Ray, 1960; Anderson, 1966, 1973; Sokoloff, 1966; Powell, 1974). The corresponding results for females and for both sexes in Davis were equivalent. The effect of the population (Davis versus Eureka) was determined for $\mathrm{F}_{4}$ males at $18^{\circ} \mathrm{C}$ (Table VI). The variance-covariance matrices were homogeneous $(\mathrm{P}=0.139)$ and the difference between the mean vectors was significant, but when considering the analysis for each variable separately, some of the groups did not differ significantly $\left(\mathrm{P}=0.158\right.$ for variable $\mathrm{L}_{1} ; \mathrm{P}=0.850$ for $\mathrm{L}_{2} ; \mathrm{P}=$ 0.399 for $\mathrm{W}$ and $\mathrm{P}=0.194$ for $\mathrm{TL})$.

A canonical analysis was made to determine the similarities between groups (Table VII, Figure 2). Although there was no homogeneity among the variance-covariance matrices, the elements of these matrices have, in general, the same sign, which justifies the application of the method (Cuadras, 1991). The first two canonical axes explain 89.5 and $97.91 \%$ of the total variance in males and females, respectively, which is more than sufficient for the bi-di-
Table IV - Effect of rearing in the laboratory on the quantitative variables $\mathrm{L}_{1}, \mathrm{~L}_{2}, \mathrm{~W}$ and $\mathrm{TL}$ with the statistical values $(\mathrm{F})$, degrees of freedom (d.f.) and significance levels. Comparison of Davis $18^{\circ} \mathrm{C} \mathrm{F}_{2}$ and Davis $18^{\circ} \mathrm{C} \mathrm{F}_{4}$ populations (200 Drosophila subobscura females measured).

\begin{tabular}{lrcc|}
\hline Variable & $\mathrm{F}$ & d.f. & Significance of $\mathrm{F}$ \\
\hline $\mathrm{L}_{1}$ & 40.082 & 1,198 & 0.000 \\
$\mathrm{~L}_{2}$ & 54.024 & 1,198 & 0.000 \\
$\mathrm{~W}$ & 113.075 & 1,198 & 0.000 \\
$\mathrm{TL}$ & 67.438 & 1,198 & 0.000 \\
Multivariate case & 34.780 & 4,195 & 0.000 \\
\hline
\end{tabular}

For abbreviations see Table I.

Table $\mathbf{V}$ - Effect of temperature on the quantitative variables $\mathrm{L}_{1}, \mathrm{~L}_{2}, \mathrm{~W}$ and TL and meristic variables PC and DC with the statistical values $(\mathrm{F})$, degrees of freedom (d.f.) and significance levels. Comparison of Eureka $18^{\circ} \mathrm{C} \mathrm{F}_{2}$ and Eureka $13^{\circ} \mathrm{C} \mathrm{F}_{2}$ populations (200 Drosophila subobscura males measured).

\begin{tabular}{|lrcc|}
\hline Variable & $\mathrm{F}$ & d.f. & Significance of $\mathrm{F}$ \\
\hline $\mathrm{L}_{1}$ & 101.653 & 1,198 & 0.000 \\
$\mathrm{~L}_{2}$ & 114.672 & 1,198 & 0.000 \\
$\mathrm{~W}$ & 111.928 & 1,198 & 0.000 \\
$\mathrm{TL}$ & 36.394 & 1,198 & 0.000 \\
$\mathrm{PC}$ & 40.064 & 1,198 & 0.000 \\
$\mathrm{DC}$ & 2.837 & 1,198 & 0.094 \\
Multivariate case & 38.290 & 6,193 & 0.000 \\
\hline
\end{tabular}

For abbreviations see Tables I and II.

Table VI - Effect of population on the quantitative variables $\mathrm{L}_{1}, \mathrm{~L}_{2}, \mathrm{~W}$ and $\mathrm{TL}$ and the meristic variables PC and DC based on the statistical values (F) with degrees of freedom (d.f.). Comparison of Davis $18^{\circ} \mathrm{C} \mathrm{F}_{4}$ and Eureka $18^{\circ} \mathrm{C} \mathrm{F}_{4}$ populations (200 Drosophila subobscura males measured).

\begin{tabular}{|lllc|}
\hline Variable & $\mathrm{F}$ & d.f. & Significance of $\mathrm{F}$ \\
\hline $\mathrm{L}_{1}$ & 2.0119 & 1,198 & 0.158 \\
$\mathrm{~L}_{2}$ & 0.036 & 1,198 & 0.850 \\
$\mathrm{~W}$ & 0.713 & 1,198 & 0.399 \\
$\mathrm{TL}$ & 1.698 & 1,198 & 0.194 \\
$\mathrm{PC}$ & 6.887 & 1,198 & 0.009 \\
$\mathrm{DC}$ & 0.015 & 1,198 & 0.092 \\
Multivariate case & 3.435 & 6,1193 & 0.003 \\
\hline
\end{tabular}

For abbreviations see Tables I and II. 
Table VII - Results of the canonical analysis of the characterized groups (see legend to Figure 2).

\begin{tabular}{|c|c|c|c|c|c|c|}
\hline \multirow[b]{2}{*}{ Function } & \multicolumn{3}{|c|}{ MALES } & \multicolumn{3}{|c|}{ FEMALES } \\
\hline & Eigenvalue & \multicolumn{2}{|c|}{ Cum. Pct. } & \multicolumn{2}{|c|}{ Eigenvalue } & Cum. Pct. \\
\hline 1 & 0.424 & \multicolumn{2}{|c|}{80.40} & & 0.556 & 86.83 \\
\hline 2 & 0.048 & \multicolumn{2}{|c|}{89.50} & & 0.071 & 97.91 \\
\hline 3 & 0.038 & \multicolumn{2}{|c|}{96.76} & & 0.011 & 99.68 \\
\hline 4 & 0.012 & \multicolumn{2}{|c|}{99.03} & & 0.002 & 100.0 \\
\hline 5 & 0.0051 & \multicolumn{2}{|c|}{100.0} & & & \\
\hline \multicolumn{7}{|c|}{ Number of significant dimensions (after Wilk's) for males: } \\
\hline Function & Lambda & \multicolumn{2}{|c|}{ Chi-square } & \multicolumn{3}{|r|}{ Significance } \\
\hline 0 & 0.634 & \multicolumn{2}{|c|}{269.882} & & 30 & 0.0 \\
\hline 1 & 0.904 & \multicolumn{2}{|c|}{60.186} & & 20 & 0.0 \\
\hline 2 & 0.947 & \multicolumn{2}{|c|}{32.387} & & 12 & 0.0012 \\
\hline 3 & 0.983 & \multicolumn{2}{|c|}{10.088} & & 6 & 0.1210 \\
\hline 4 & 0.995 & \multicolumn{2}{|c|}{3.029} & & 2 & 0.2199 \\
\hline \multicolumn{7}{|c|}{ Number of significant dimensions (after Wilk's) for females: } \\
\hline Function & Lambda & Chi-s & quare & & d.f. & Significance \\
\hline 0 & 0.592 & 311. & 100 & & 20 & 0.0 \\
\hline 1 & 0.921 & 48. & 613 & & 12 & 0.0 \\
\hline 2 & 0.987 & & 895 & & 6 & 0.2459 \\
\hline 3 & 0.998 & & 223 & & 2 & 0.5425 \\
\hline Coordinates of & f the mean & n groups: & & & & \\
\hline Group & Index & Function 1 & Funct & on 2 & Function 1 & 1 Function 2 \\
\hline Eureka $18^{\circ} \mathrm{F}_{2}$ & 1 & -0.92001 & -0.14 & & -1.01323 & 0.23210 \\
\hline Davis $18^{\circ} \mathrm{F}_{2}$ & 2 & -0.84654 & 0.08 & & -1.02951 & -0.17601 \\
\hline Eureka $13^{\circ} \mathrm{F}_{2}$ & 3 & 0.77856 & -0.00 & & 0.55582 & -0.14499 \\
\hline Davis $13^{\circ} \mathrm{F}_{2}^{2}$ & 4 & 0.44738 & -0.28 & & 0.41042 & -0.42213 \\
\hline Eureka $18^{\circ} \stackrel{2}{F}_{4}$ & 5 & 0.31569 & -0.06 & & 0.81868 & 0.31388 \\
\hline Davis $18^{\circ} \mathrm{F}_{4}^{4}$ & 6 & 0.22502 & 0.41 & & 0.25782 & 0.19715 \\
\hline
\end{tabular}

Cum. Pct., Cumulative percentage.

mensional representation of the characterized groups. The $18^{\circ} \mathrm{CF}_{2}$ group from both populations clearly separates from the other two groups $\left(18^{\circ} \mathrm{C} \mathrm{F}_{4}\right.$ and $\left.13^{\circ} \mathrm{C} \mathrm{F}_{2}\right)$, both in males and females.

\section{DISCUSSION}

In general, the response of body size to temperature is considered to be adaptive and due to natural selection. The developmental system responding to the growth environment could be a phenomenon of adaptive plasticity (Schmalhausen, 1949; Bradshaw, 1965; Gomulkiewicz and Kirkpatrick, 1992). The increase in body size and cell size resulting from development at low temperature has also been considered a case of adaptive phenotypic plasticity (Partridge et al., 1994). David et al. (1994) also detected a response of wing and thorax lengths to temperature but found significant variations between lines and significant line-temperature interactions, demonstrating different norms of reaction among the various lines. Alto- gether, in the present study the main conclusions that can be drawn from the MANOVA results and the canonical analyses of the characterized groups are the following: temperature, although important, is not the only factor that explains the phenotypic differentiation of Drosophila flies kept in the laboratory. The size of the flies reared in the laboratory at $18^{\circ} \mathrm{C}$ for four generations was equivalent to the size of the flies reared at $13^{\circ} \mathrm{C}$ for only two generations. The response was much clearer for continuous variables. Meristic variables (number of teeth of the sex combs) did not differentiate appreciably. The multivariate mean tests were always significant, whether we consider laboratory rearing, temperature or the population effects. This is expected due to the sensitivity of the multivariate techniques and to the sample size. On the other hand, the univariate tests show similarity between the Davis and Eureka populations. As pointed out above, the colonization of the American continent by D. subobscura is a recent phenomenon. The colonizing populations are very much alike genetically (Prevosti et al., 1988 and 1989; Ayala et al., 1989; Mestres et al., 1990, 1992, 1995; Balanyà et al., 1994). This genetic similarity could explain the resemblance between Eureka and Davis populations in terms of quantitative traits: the multifactorial genotype controlling these traits would not have differentiated significantly since the colonization took place, in spite of the environmental differences between these two localities (Pascual et al., 1993). The two populations analyzed still show great phenotypic plasticity in spite of the genetic bottleneck during the founder event (Prevosti et al., 1989). This result is in agreement with the empirical evidence obtained from Drosophila and housefly populations, supported by several theoretical models (Bryant et al. 1986; Goodnight, 1987; Lewin, 1987; Carson, 1990) indicating that genetic variance available to selection may actually increase following a population bottleneck.

Finally, analysis of the correlation of quantitative traits with environmental factors has been widely used to detect natural selection in the wild (Ford, 1975; Endler, 1986), and some data are available on the existence of latitudinal clines for quantitative traits in Palearctic populations of D. subobscura (Prevosti, 1955, Misra and Reeve, 1964; Pfriem, 1983; Pegueroles et al., 1995). Nevertheless, studies of this kind rely heavily on all samples being reared under the same laboratory conditions prior to measurement. As it is clearly shown in our analysis of the effect of rearing in the laboratory, all samples should be measured immediately after being collected, or at least be kept in the laboratory for the same period of time, to get reliable estimates of the existence of natural selection acting on quantitative traits in natural populations.

\section{ACKNOWLEDGMENTS}

Research supported by Grant PB86-0014 of the Dirección General de Investigación Científica y Técnica (Spain). We are grate- 


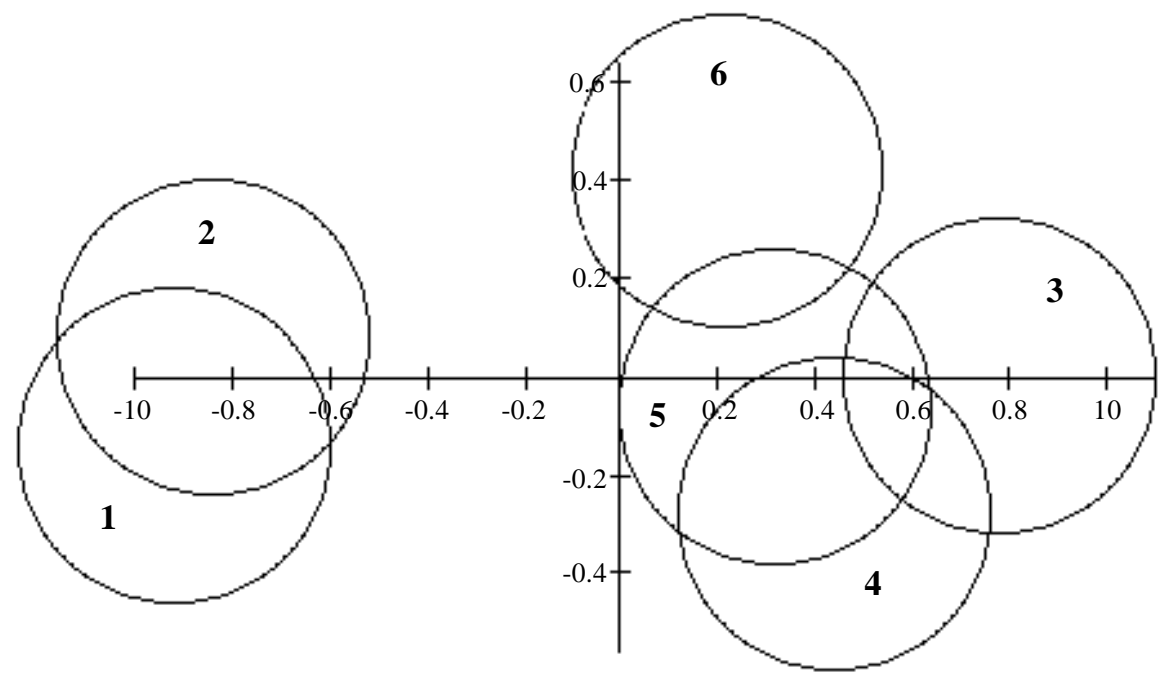

Males

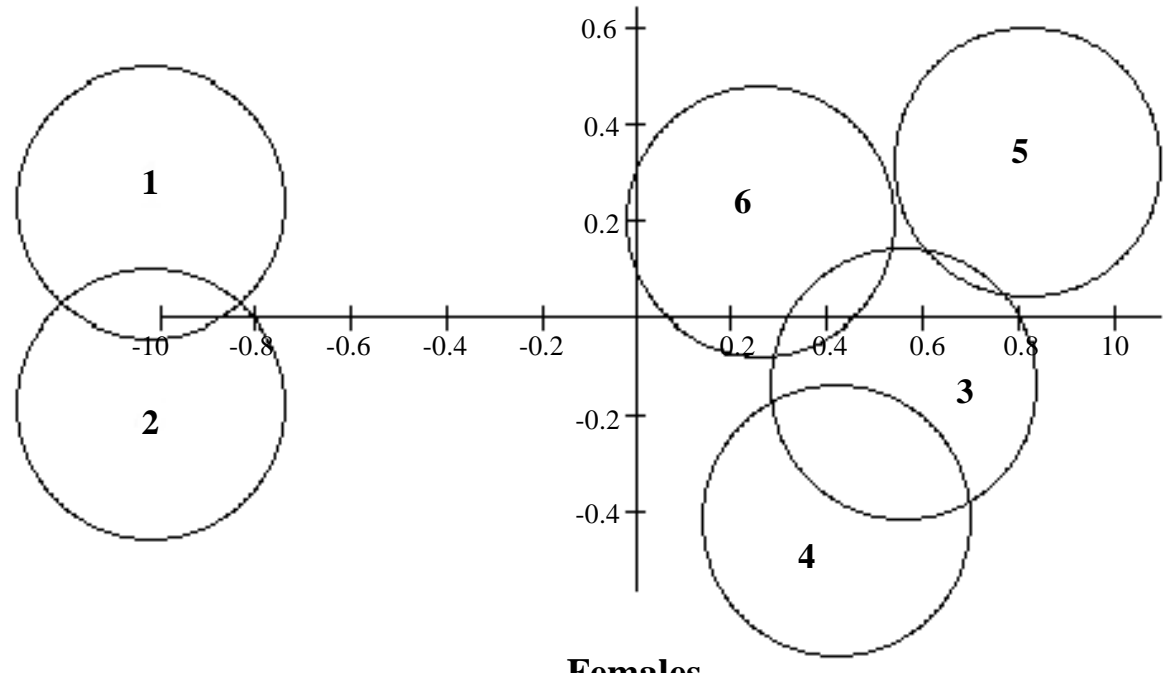

Females

Figure 2 - Canonical representation of the characterized groups (1. Eureka $18^{\circ} \mathrm{CF}_{2}, 2$. Davis $18^{\circ} \mathrm{C} \mathrm{F}_{2}, 3$. Eureka $13^{\circ} \mathrm{C} \mathrm{F}$, 4. Davis $13^{\circ} \mathrm{C}$ $\mathrm{F}_{2}$, 5. Eureka $18^{\circ} \mathrm{C} \mathrm{F}_{4}$, and 6. Davis $18^{\circ} \mathrm{C} \mathrm{F}_{4}$ ) at the $90 \%$ confidence level (radii $=0.33$ for males and 0.28 for females). For both populations (Eureka and Davis) the group $18^{\circ} \mathrm{C} \mathrm{F}_{2}$ clearly separates from the other two groups $\left(18^{\circ} \mathrm{C}_{4}\right.$ and $\left.13^{\circ} \mathrm{C} \mathrm{F}_{2}\right)$.

ful to Dr. C. Arenas (Dept. d' Estadística, Universitat de Barcelona) for her valuable suggestions. We also thank Mr. Robin Rycroft (S.A.L., Universitat de Barcelona) for the English correction.

\section{RESUMO}

A plasticidade fenotípica de alguns caracteres quantitativos foi estudada em duas populações colonizadoras de Drosophila subobscura (Davis e Eureka, Califórnia). Analisaram-se tanto o efeito da temperatura como o da criação em laboratório. A criação em laboratório durante quatro gerações a $18^{\circ} \mathrm{C}$ aumentou significativamente o comprimento da asa e da tíbia. Este incremento foi semelhante ao obtido quando as moscas foram cultivadas a $13^{\circ} \mathrm{C}$ durante duas gerações. $\mathrm{O}$ ambiente de temperatura baixa pode ser considerado mais estressante para as fêmeas, pois elas apresentaram um aumento na variância fenotípica. As duas populações analisadas apresentaram uma grande plasticidade fenotípica, apesar do "gargalo" genético produzido durante o processo colonizador. Nossos estudos mostram que a manutenção das moscas no laboratório por um período de tempo relativamente curto é capaz de mudar significativamente alguns caracteres quantitativos, sendo fundamental analisar as moscas imediatamente após capturá-las, para se obterem estimativas confiáveis na análise de tais caracteres nas populações naturais.

\section{REFERENCES}

Anderson, W.W. (1966). Genetic divergence in M. Vetukhiv's experimental populations of Drosophila pseudoobscura. Genet. Res. 7: 255-266.

Anderson, W.W. (1973). Genetic divergence in body size among experi- 
mental populations of Drosophila pseudoobscura kept at different temperatures. Evolution 27: 278-284.

Ayala, F.J., Serra, L. and Prevosti, A. (1989). A grand experiment in evolution: the Drosophila subobscura colonization of the Americas. Genome 31: 246-255.

Balanyà, J., Segarra, C., Prevosti, A. and Serra, L. (1994). Colonization of America by Drosophila subobscura: The founder event and a rapid expansion. J. Hered. 85: 427-432.

Barker, J.S.F. and Krebs, R.A. (1995). Genetic variation and plasticity of thorax length and wing length in Drosophila aldrichi and D. buzzatii. J. Evol. Biol. 8: 689-709.

Beckenbach, A.T. and Prevosti, A. (1986). Colonization of North America by the European species Drosophila subobscura and D. ambigua. Am. Midl. Nat. 115: 10-18.

Bradshaw, A.D. (1965). Evolutionary significance of phenotypic plasticity in plants. Adv. Genet. 13: 115-155.

Brncic, D., Prevosti, A., Budnik, M., Monclús, M. and Ocaña, J. (1981). Colonization of Drosophila subobscura in Chile. I. First population and cytogenetic studies. Genetica 56: 3-9.

Bryant, E.H., McCommas, S.A. and Combs, L.M. (1986). The effect of an experimental bottleneck upon quantitative genetic variation in the housefly. Genetics 114: 1191-1211.

Burla, H. and Taylor, C.E. (1982). Increase of phenotypic variance in stressful environments. J. Hered. 73: 142.

Carson, H.L. (1990). Increased genetic variance after a population bottleneck. Trends Ecol. Evol. 5: 228-230.

Cavicci, S., Guerra, D., Natali, V., Pezzoli, C. and Giorgi, G. (1989). Temperature-related divergence in experimental populations of Drosophila melanogaster. II. Correlation between fitness and body dimensions. J. Evol. Biol. 2: 235-251.

Cuadras, C.M. (1991). Métodos de Análisis Multivariante. 2nd edn. Promociones y Publicaciones Universitarias S.A., Barcelona.

David, J.R., Moretau, B., Gauthier, J.P., Pétavy, G., Stockel, A. and Imasheva, A.G. (1994). Reaction norm of size characters in relation to growth temperature in Drosophila melanogaster: an isofemale line analysis. Genet. Sel. Evol. 26: 229-251.

Endler, J.A. (1986). Natural Selection in the Wild. Princeton Univ. Press, Princeton, NJ.

Ford, E.B. (1975). Ecological Genetics. 4th edn. Chapman \& Hall, London.

Gomulkiewicz, R. and Kirkpatrick, M. (1992). Quantitative genetics and the evolution of reaction norms. Evolution 46: 390-411.

Goodnight, C.J. (1987). On the effect of founder events on epistatic genetic variance. Evolution 41: 80-91.

Krimbas, C.B. (1993). Drosophila subobscura. Biology, Genetics and Inversion Polymorphism. Verlag Dr. Kovac, Hamburg.

Lewin, R. (1987). The surprising genetics of bottlenecked flies. Science 235: 1325-1327.

Mestres, F., Pegueroles, G., Prevosti, A. and Serra, L. (1990). Colonization of America by Drosophila subobscura: Lethal genes and the problem of the $\mathrm{O}_{5}$ inversion. Evolution 44: 1823-1836.

Mestres, F., Balañà, J., Segarra, C., Prevosti, A. and Serra, L. (1992). Colonization of America by Drosophila subobscura: Analysis of the $\mathrm{O}_{5}$ inversions from Europe and America and their implications for the colonizing process. Evolution 46: 1546-1568.

Mestres, F., Serra, L. and Ayala, F.J. (1995). Colonization of the Ameri- cas by Drosophila subobscura: Lethal-gene allelism and association with chromosomal arrangements. Genetics 140: 1297-1305.

Misra, R.K. and Reeve, E.C.R. (1964). Clines in body dimension in populations of Drosophila subobscura. Genet. Res. 5: 240-256.

Partridge, L., Barrie, B., Fowler, K. and French, V. (1994). Evolution and development of body size and cell size in Drosophila melanogaster in response to temperature. Evolution 48: 1269-1276.

Pascual, M., Ayala, F.J., Prevosti, A. and Serra, L. (1993). Colonization of North America by Drosophila subobscura: Ecological analysis of three communities of drosophilids in California. Z. Zool. Syst. Evolutionsforsch 31: 216-226.

Pegueroles, G., Papaceit, M., Quintana, A., Guillén, A. Prevosti, A. and Serra, L. (1995). An experimental study of evolution in progress: clines for quantitative traits in colonizing and Palearctic populations of Drosophila. Evol. Ecol. 9: 453-465.

Pfriem, P. (1983). Latitudinal variation in wing size in Drosophila subobscura and its dependence on polygenes of chromosome $\mathrm{O}$. Genetica 61: 221-232.

Powell, J.R. (1974). Temperature related divergence in Drosophila body size. J. Hered. 65: 257-258.

Prevosti, A. (1955). Geographical variability in quantitative traits in populations of Drosophila subobscura. Cold Spring Harbor Symp. Quant. Biol. 20: 294-299.

Prevosti, A., García, M.P., Serra, L., Aguadé, M., Ribó, G. and Sagarra, E. (1983). Association between allelic isozyme alleles and chromosomal arrangements in European populations and Chilean colonizers of Drosophila subobscura. Isozymes 10: 171-191.

Prevosti, A., Ribó, G., Serra, L., Aguadé, M., Balañà, J., Monclús, M. and Mestres, F. (1988). Colonization of America by Drosophila subobscura: Experiment in natural populations that supports the adaptive role of chromosomal-inversion polymorphism. Proc. Natl. Acad. Sci. USA 85: 5597-5600.

Prevosti, A., Serra, L., Aguadé, M., Ribó, G., Mestres, F., Balañà, J. and Monclús, M. (1989). Colonization and establishment of the Palearctic species Drosophila subobscura in North and South America. In: Evolutionary Biology of Transient Unstable Populations (Fontdevila, A., ed.). Springer-Verlag, Berlin, pp. 114-129.

Ray, C. (1960). The application of Bergmann's and Allen's rules to the Poikilotherms. J. Morphol. 106: 85-108.

Robertson, F.W. and Reeve, E. (1952). Studies in quantitative inheritance: I. The effects of selection of wing and thorax length in Drosophila melanogaster. J. Genet. 50: 414-448.

Schmalhausen, I.I. (1949). Factors of Evolution: The Theory of Stabilizing Selection. University of Chicago Press, Chicago.

Sokoloff, A. (1966). Morphological variation in natural and experimental populations of Drosophila pseudoobscura and D. persimilis. Evolution 20: 49-71.

Via, S. (1994). The evolution of phenotypic plasticity: what do we really know? In: Ecological Genetics (Real, L.A., ed.). Princeton University Press, Princeton, pp. 35-57.

Via, S. Gomulkiewicz, R., De Jong, G., Scheiner, S.M., Schlichting, C.D. and Van Tienderen, P.H. (1995). Adaptive phenotypic plasticity: consensus and controversy. Trends Ecol. Evol. 10: 212-217.

(Received July 3, 1998) 